\title{
Fatty acid composition of buffalo and bovine milk as affected by roughage source - silage versus hay
}

\author{
Pencho Penchev ${ }^{1 *}$, Yordanka llieva1', Tatyana Ivanova², Rumen Kalev ${ }^{3}$ \\ ${ }^{1}$ Department of Buffalo, Agricultural Institute, Shumen, Bulgaria; ${ }^{2}$ Department of Breeding and Reproduction, Agricultural Institute, Shumen, \\ Bulgaria; ${ }^{3}$ Agricultural Research Centre, Targovishte, Bulgaria
}

\section{A B S TR A C T}

\begin{abstract}
With the aim to test the effects of roughage source and species on fatty acid (FA) composition of milk, an experiment was initiated on 10 buffalo and 12 bovine cows, allotted by the analog method into control (fed silage) and experimental (fed hay) groups. Milk samples were taken individually at three test days - prior to experiment (TDO), after one (TD1) and two (TD2) months from the start - and subjected to fatty acid analysis. The effects and co-effects were tested by two-way ANOVA's for TD1 and TD2 data, while for the assessment of the differences between species at TDO - by one-way ANOVA. Compared to the bovine, at TDO the buffalo milk displayed significantly lower contents of C8:0-C14:0 and higher of C18:1, total SFA being lower; PUFA were significantly lower, concerning also C18:2 (P $\leq 0.01$ ), while MUFA (especially $\mathrm{C} 18: 1$ ) were higher $(\mathrm{P} \leq 0.05)$. In the two experimental groups at TD2 PUFA and particularly $\mathrm{C} 18: 2$ were higher $(P \leq 0.001)$. In the buffaloes fed hay $C 18: 1$ and $C 18: 3$ were also established higher $(P \leq 0.001)$ with noticeably lower SFA, as compared to silage diet. It was contrary in the bovine cows, the experimental group having higher C8:0-C15:0 (P $\leq 0.001)$ and lower UFA portion. Despite having similar FA profile to the bovine milk, the bubaline milk displayed better $\mathrm{n} 6 / \mathrm{n} 3$ ratio; but lower PUFA fraction with tendency to improve, together with MUFA, when roughage source is shifted from silage to hay.
\end{abstract}

Keywords: Bovine; Buffalo; Fatty acids; Hay; Silage

\section{INTRODUCTION}

Milk of ruminant origin and its derivative dairy products constitute considerable portion of human diet and that is why there is definite criticism against their saturated nature. According to FAO, saturated fatty acids (SFA) should provide no more than $10 \%$ of total calories (FAO/ WHO, 2003). On the other hand, some studies prove the reduction of cardio vascular and cancer risk with the consumption of milk, since, as a ruminant product, it is a source of the beneficial conjugated linoleic acid (Parodi, 2004) but also through the protective effect of some SFA's (Knopp and Retzlaff, 2004; Dabadie et al., 2005) and even the immunosuppressive effect of the polyunsaturated fatty acids (Newsholme et al., 1993).

While the SFA's are absorbed into the bloodstream through the walls of the rumen, abomasum or small intestine, the majority of the beneficial unsaturated fatty acids (UFA) are subjected to the dramatic oxidation and hydrogenation processes that take place in the rumen (Bauman et al., 2006). Despites, system of feeding has been established to affect fatty acid (FA) profile of milk to certain extent (Dhiman et al., 1999; Fernandes et al., 2007; Beyero et al., 2015), although this is not attributed to the intake of functional FA's but to the different ruminal biohydrogenation and $\Delta$ 9-desaturase activity (Shingfield et al., 2005; Kalač and Samková, 2010). This is relevant to the policy of the World Health Organization (FAO/WHO, 2003) to urge producers to improve the lipid profile of the foods of ruminant origin.

The main roughage fed to large ruminants in the winter in Bulgaria is silage. It has lower level of dry matter but higher energy content and higher functional FA's than hay (Shingfield et al., 2005; Kalač and Samková, 2010), and leads to higher productivity at lower price, but at the end of the winter season it is often insufficient and its replacement is indispensable. There are series of studies comparing the effect of different sources of roughage - including cereal and leguminous silages - on the lipid profile of bubaline and bovine milk (Shingfield et al., 2005;

\footnotetext{
*Corresponding author:

Pencho Penchev, Buffalo Dept., Agricultural Institute - Shumen; 3 Simeon Veliki Blvd., Shumen 9700, Bulgaria;

Cell: +359 88 44113636; E-mail: pen.penchev@gmail.com
} 
Nielsen et al., 2006; Fernandes et al., 2007). But those considering in particular maize silage versus hay are few and somehow inconsistent in dairy cattle (Dhiman et al., 1999; Staszak, 2007; Bernardini et al., 2010) and scarce in the water buffalo. Comparisons between the two species on experimental basis are also absent on national scale.

On this background, a parallel experiment on buffalo and bovine cows was initiated with the aim to study the effect of the shift in roughage source from silage to hay at the end of the winter season on FA composition of milk.

\section{MATERIAL AND METHODS}

\section{Experimental design - animals and feeding}

For the aim of the experiment, animals from the experimental farm of Agricultural Institute - Shumen were assigned -10 buffaloes (Bubalus bubalis) of the Bulgarian Murrah breed and 12 bovine cows (Bos taurus) of the Bulgarian Black and White breed, both dairy-purpose breeds. The housing system for large ruminants applied on the farm is tie stalls with exercise yard. The feeding is traditional with silage as main roughage in the winter season, ensiling being done with the inoculant 11CFT (Pioneer Hi-Bred International, Inc.), containing Lactobacillus buchneri and Lactobacillus casei.

The experiment was launched on February 18-th. Prior to its start (pre-experimental period) a control and an experimental group were formed within each species, allotted by the analog method regarding parity (first, second, and third-plus) and lactation stage (first to third month postpartum). The experiment used the same housing system as before its start, the two groups of buffaloes in one barn, and those of bovine cows in another one. In the per se experimental period the control buffaloes $(n=5)$ and cows $(n=6)$ continued to be fed the same ration, while for the other group of each species (experimental) silage was replaced with hay on dry matter base for two months, so that the experimental buffaloes $(n=5)$ received additional $8 \mathrm{~kg}$ leguminous hay per capita per day, while the experimental cows $(n=6)-10 \mathrm{~kg}$. The concentrate feed has the following composition: wheat grain $-15 \%$, barley grain $-12 \%$, corn grain $-56 \%$, wheat bran $-10 \%$, sunflower oilcake $-5 \%$, dicalcium phosphate $0.6 \%$, salt $-0.4 \%$, and chalk $-1 \%$. In this way $1 \mathrm{~kg}$ of it provides $1629 \mathrm{kcal}$ energy and $96 \mathrm{~g}$ digestible protein. The whole daily rations of the lactating buffaloes and bovine cows with their nutritional value are presented in Table 1.

\section{Sampling and laboratory analysis}

Three test days (TD) were carried out. One of them was in the day prior to the start of the experimental period -
Table 1: Feeding scheme of the experiment with composition and nutritional value of diets - quantity $(\mathrm{kg})$, energy (E, kcal), and digestible protein (DP, g), per capita per day

\begin{tabular}{lccccc}
\hline Groups & $\begin{array}{c}\text { Concentrate } \\
\text { feed }\end{array}$ & $\begin{array}{c}\text { Alfalfa } \\
\text { hay }\end{array}$ & $\begin{array}{c}\text { Wheat } \\
\text { straw }\end{array}$ & $\begin{array}{c}\text { Maize } \\
\text { silage }\end{array}$ & $\begin{array}{c}\text { Total } \\
\text { in diet }\end{array}$ \\
\hline $\begin{array}{l}\text { Buffaloes control }(n=5) \\
\text { kg }\end{array}$ & 3.5 & 1 & 3 & 25 & \\
E & 5702 & 955 & 1197 & 12469 & 20323 \\
DP & 336 & 136 & 20 & 368 & 860 \\
Buffaloes experimental & & & & & \\
( $n=5)$ & & & & & \\
kg & 3.5 & 9 & 3 & - & \\
E & 5702 & 8593 & 1197 & - & 15492 \\
DP & 336 & 1224 & 20 & - & 1580 \\
Bovine cows control & & & & & \\
( $n=6)$ & & & & & \\
kg & 9 & 2 & 2 & 30 & \\
E & 14661 & 1910 & 798 & 14963 & 32332 \\
DP & 864 & 272 & 14 & 441 & 1591 \\
Bovine cows & & & & & \\
experimental (n=6) & & & & & \\
kg & 9 & 12 & 2 & - & \\
E & 14661 & 11457 & 798 & - & 26916 \\
DP & 864 & 1632 & 14 & - & 2510 \\
\hline
\end{tabular}

test day 0 (TD0) in February. The other two were in the experimental period: test day 1 (TD1) - one month from the start (March); and test-day 2 (TD2) - two months from the start (April). At each test day test samples of milk from the evening milking were taken from each animal within each group of the two species and delivered cooled at $4^{\circ} \mathrm{C}$ until the next morning to the laboratory.

The lipid analysis was carried out at the Laboratory of the Department of Ecology and Quality at the Institute of Animal Science, Kostinbrod. For lipid extraction was applied the method of Hara and Radin (1978) and from total lipids were prepared isopropyl esters. The FA analysis was carried out on a Carlo-Erba gas chromatograph with hydrogen as carrier gas and a capillary column (BP21, 30x0.53 mm; film thickness $0.5 \mu \mathrm{m}$ ) under the following temperature conditions of analysis: initial temperature of oven $70^{\circ} \mathrm{C}$ in $2 \mathrm{~min}$ risen to $170^{\circ} \mathrm{C}$ at $15^{\circ} \mathrm{C} / \mathrm{min}$, after $1 \mathrm{~min}$ retention risen to $205^{\circ} \mathrm{C}$ at $10^{\circ} \mathrm{C} / \mathrm{min}$ and $3 \mathrm{~min}$ retention; detector $250^{\circ} \mathrm{C}$; injector $-260^{\circ} \mathrm{C}$.

\section{Data processing and statistical analyses}

Two-way ANOVA's were carried out separately for TD1 and TD2 to analyze the effect of species and diet as well as their interaction (co-effect) on the FA profile of milk during the experiment. One-way ANOVA was applied for evaluation of the differences in the FA composition between species during adaptation (TD0). The results for each FA were presented in tabular form as least-square mean (LSM) and root mean square error (RMSE). All 
analyses were performed in the JMP Software (JMP, Version 7, SAS Institute Inc., Cary, NC, 1989-2007).

The atherogenicity (IA) and thrombogenicity (IT) index were calculated using the equations of Ulbricht and Southgate (1991) as follows:

$\mathrm{IA}=(\mathrm{C} 12: 0+4 * \mathrm{C} 14: 0+\mathrm{C} 16: 0) / \mathrm{UFA}$

$\mathrm{IT}=(\mathrm{C} 14: 0+\mathrm{C} 16: 0+\mathrm{C} 18: 0) /\left(0.5^{*} \mathrm{MUFA}+0.5^{*} \mathrm{n} 6+\right.$ $\left.3 *_{n} 3+n 3 / n 6\right)$.

\section{RESULTS}

\section{Pre-experimental period (TD0, February)}

Fig. 1 presents the FA composition of the milk from the two studied ruminants in the pre-experimental period (TD0), showing that in both greatest is the percentage of C16:0 followed by C18:1 and C14:0. Since Chart "a" (Fig. 1a) is not indicative enough of the existing differences especially in the lowly presented FA's, a Chart "b" was built to demonstrate the relative differences of the bubaline milk out of the bovine, the FA's contents of the latter taken as base (zero) values. The comparison shows that during the adaptation period in the buffalo milk C8:0, C10:0 and C12:0 were by 30 to 45 percent significantly lower $(\mathrm{P} \leq 0.01, \mathrm{P} \leq 0.001)$, which applies to lesser extent also to C6:0, C15:0 and even to C14:0 though only as a tendency $(\mathrm{P}>0.05)$. In the same time, the value of $\mathrm{C} 18: 2$ is also lower in the bubaline milk ( $\mathrm{P} \leq 0.001)$. In the buffalo cows significantly higher was found to be the percentage of $\mathrm{C} 17: 0, \mathrm{C} 18: 0(\mathrm{P} \leq 0.001)$, and more essentially of $\mathrm{C} 18: 1$ though by only 15 percent and with marginal statistical significance $(\mathrm{P} \leq 0.05)$. The contents of the most highly

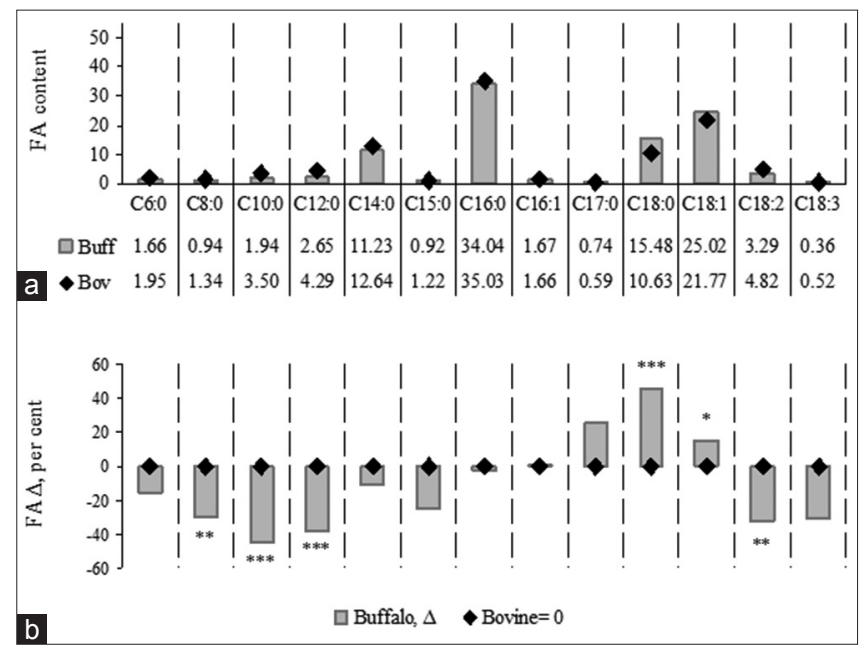

Fig 1. Fatty acid profile of buffalo milk as compared to bovine at test day 0: a) absolute values; b) relative differences (FA $\Delta$ ) - bovine FA's taken as base (zero) values; F-test of effect of species: ${ }^{* *} \mathrm{P} \leq 0.001$, ${ }^{*} \mathrm{P} \leq 0.01$, and ${ }^{*} \mathrm{P} \leq 0.05$ presented C16:0 have very close values. The differences in the contents of the individual mono- (MUFA) and polyunsaturated (PUFA) fatty acids reflected on their total amounts - MUFA showed higher content in the buffalo than in the bovine milk $(\mathrm{P} \leq 0.05)$, however PUFA were lower $(\mathrm{P} \leq 0.01)$. Despite of its significantly higher contents of the short- and middle-chain FA's, the total amount of the saturated fatty acids (SFA) of the bovine milk was only slightly higher, due to the lower contents C17:0 and C18:0.

\section{Experimental period (TD1 and TD2)}

The results from the per se experimental period indicate that, in comparison to TD1 (Table 2), the ANOVA for TD2 (Table 3) was established to have better statistical significance of the effects and co-effects and markedly lower RSME values.

\section{Table 2: Effect of species (Sp) and diet (Di) and their} co-effect $(\mathrm{Sp} * \mathrm{Di})$ at TD1

\begin{tabular}{|c|c|c|c|c|c|c|c|c|}
\hline \multirow{3}{*}{$\begin{array}{l}\text { Fatty } \\
\text { acids }\end{array}$} & \multicolumn{4}{|c|}{ LSM } & \multirow[t]{3}{*}{ RMSE } & \multirow{2}{*}{\multicolumn{3}{|c|}{$\begin{array}{l}\text { Effects/ } \\
\text { co-effect }\end{array}$}} \\
\hline & \multicolumn{2}{|c|}{ Buffalo } & \multicolumn{2}{|c|}{ Bovine } & & & & \\
\hline & Silage & Hay & Silage & Hay & & $S p$ & $\mathrm{Di}$ & Sp*Di \\
\hline C6:0 & 1.88 & 1.80 & 1.83 & 1.50 & 0.34 & NS & NS & NS \\
\hline C8:0 & 1.03 & 0.97 & 1.27 & 0.87 & 0.25 & NS & * & NS \\
\hline C10:0 & 2.10 & 1.99 & 3.65 & 1.89 & 0.74 & NS & * & * \\
\hline C12:0 & 2.81 & 2.62 & 4.51 & 2.32 & 0.87 & NS & ** & * \\
\hline $\mathrm{C} 14: 0$ & 12.07 & 14.03 & 12.47 & 9.42 & 3.10 & NS & NS & NS \\
\hline C15:0 & 1.22 & 1.47 & 1.49 & 1.23 & 0.53 & NS & NS & NS \\
\hline C16:0 & 31.49 & 27.50 & 33.58 & 28.33 & 3.66 & NS & $* *$ & NS \\
\hline C16:1 & 2.20 & 2.03 & 1.80 & 2.31 & 0.53 & NS & NS & NS \\
\hline C17:0 & 0.63 & 1.23 & 0.83 & 1.14 & 0.49 & NS & * & NS \\
\hline C18:0 & 14.89 & 14.90 & 11.01 & 12.93 & 2.97 & * & NS & NS \\
\hline C18:1 & 26.22 & 27.31 & 21.32 & 33.23 & 4.41 & NS & $* *$ & * \\
\hline C18:2 & 3.14 & 3.91 & 6.15 & 4.54 & 1.00 & $* * *$ & NS & * \\
\hline C18:3 & 0.31 & 0.21 & 0.33 & 0.24 & 0.11 & NS & * & NS \\
\hline
\end{tabular}

Probability of F-test: ${ }^{*} \mathrm{P} \leq 0.05 ;{ }^{* *} \mathrm{P} \leq 0.01 ;{ }^{* * *} \mathrm{P} \leq 0.001$; NS: Nonsignificant

Table 3: Effect of species (Sp) and diet (Di) and their co-effect $\left(\mathrm{Sp}^{\star} \mathrm{Di}\right)$ at TD2

\begin{tabular}{|c|c|c|c|c|c|c|c|c|}
\hline \multirow{3}{*}{$\begin{array}{l}\text { Fatty } \\
\text { acids }\end{array}$} & \multicolumn{4}{|c|}{ LSM } & \multirow[t]{3}{*}{ RMSE } & \multirow{2}{*}{\multicolumn{3}{|c|}{$\begin{array}{l}\text { Effects/ } \\
\text { co-effect }\end{array}$}} \\
\hline & \multicolumn{2}{|c|}{ Buffalo } & \multicolumn{2}{|c|}{ Bovine } & & & & \\
\hline & Silage & Hay & Silage & Hay & & $\mathrm{Sp}$ & $\mathrm{Di}$ & Sp*Di \\
\hline C6:0 & 4.03 & 3.18 & 2.81 & 2.84 & 0.23 & $* * *$ & $* * *$ & $* * *$ \\
\hline C8:0 & 2.03 & 1.89 & 1.30 & 1.84 & 0.27 & $* *$ & $* *$ & ** \\
\hline C10:0 & 3.34 & 2.99 & 2.30 & 4.64 & 0.37 & NS & NS & $* \star *$ \\
\hline C12:0 & 3.77 & 3.66 & 2.92 & 6.24 & 0.48 & $* \star \star$ & $\star \star \star *$ & 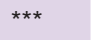 \\
\hline C14:0 & 13.55 & 13.92 & 10.64 & 14.05 & 0.76 & $* * *$ & $* * *$ & $* * *$ \\
\hline C15:0 & 1.18 & 0.59 & 0.84 & 1.13 & 0.19 & NS & NS & $* * *$ \\
\hline C16:0 & 32.43 & 33.23 & 39.18 & 39.57 & 1.15 & $* * *$ & NS & NS \\
\hline C16:1 & 1.64 & 1.92 & 2.00 & 1.84 & 0.23 & NS & NS & NS \\
\hline C17:0 & 2.58 & 0.63 & 0.63 & 0.54 & 0.13 & $* * *$ & $* * *$ & $* * *$ \\
\hline C18:0 & 12.25 & 12.72 & 13.53 & 7.82 & 0.65 & $* * *$ & $\star \star \star *$ & $* * *$ \\
\hline C18:1 & 21.24 & 23.01 & 21.67 & 16.34 & 0.81 & $* * *$ & $\star \star \star *$ & $* \star \star$ \\
\hline C18:2 & 1.38 & 1.50 & 1.63 & 2.60 & 0.26 & $* * *$ & $\star \star * \star$ & $* \star *$ \\
\hline C18:3 & 0.54 & 0.73 & 0.51 & 0.45 & 0.08 & $* * *$ & NS & $* \star \star$ \\
\hline
\end{tabular}

Probability of F-test: ${ }^{* *} \mathrm{P} \leq 0.01 ;{ }^{* *} \mathrm{P} \leq 0.001$; NS: Nonsignificant 
The replacement of the silage with hay after one month (Table 2) did not affect the content of C6:0 and C8:0 in both species, while it significantly reduced the percentage of $\mathrm{C} 10: 0(\mathrm{P} \leq 0.05)$ and $\mathrm{C} 12: 0(\mathrm{P} \leq 0.01)$ in the animals of the two experimental groups, more pronounced in the cows as the significant interactions between diet and species $(\mathrm{P} \leq 0.05)$ indicate. The hay-based diet is associated with significantly lower content of $\mathrm{C} 16: 0(\mathrm{P} \leq 0.01)$ and with higher $\mathrm{C} 17: 0(\mathrm{P} \leq 0.05)$ and $\mathrm{C} 18: 1(\mathrm{P} \leq 0.01)$, the latter being especially expressed in the cows by the significant diet-species co-effect $(\mathrm{P} \leq 0.05)$. The percentage of $\mathrm{C} 18: 3$ (n3) was lower in the groups fed hay, compared to silage $(\mathrm{P} \leq 0.05)$. While in the buffaloes C18:2 (n6) was found higher in the experimental group (hay), in the cows it was the other way round $(\mathrm{P} \leq 0.05)$.

At TD2 (Table 3), the effect of the diet on the FA composition depended on the species and the factors interacted significantly in general $(\mathrm{P} \leq 0.001)$. In comparison to silage as roughage source, in the buffaloes consuming hay the contents of the FA's with 6 to 12 carbon atoms and that of C17:0 were established to be lower (C14:0 having close values), while the proportion of the UFA's - higher, proven at $\mathrm{P} \leq 0.001$ except for $\mathrm{C} 16: 1$. In the cows the effect is contrary, the middle-chain (C8:0 to C15:0) FA's are higher $(\mathrm{P} \leq 0.001)$ when the ration is based on hay, the relative difference in C14:0 being 32 per cent. Most of the longchain acids are lower in the milk of the bovine cows from the experimental group $(\mathrm{P} \leq 0.001)$; the exception is $\mathrm{C} 18: 2$ which, like in the bubaline species, showed higher value in the hey-diet group $(\mathrm{P} \leq 0.001)$. Hence, with the shift of roughage source from silage to hay the proportion of the UFA fraction in the buffalo milk was found to improve while in the bovine - to decrease, and this concerns mostly MUFA in particular; i.e, the buffaloes fed hay produced milk with higher MUFA but lower PUFA.

With regard to species comparison, there is remarkable difference in the percentage of the most highly-presented FA in milk, C16:0, being higher in the cows as compared to the buffaloes $(\mathrm{P} \leq 0.001)$, which was not apparent in the preexperimental period and opposite at TD1. At its expense, the other SFA's are generally higher in the buffaloes.

\section{Health-related indicators}

The indices of atherogenicity (IA) and thrombogenicity (IT) and the $\mathrm{n} 6 / \mathrm{n} 3$ ratio in buffaloes and cows, calculated on the base of the FA's contents by test day and diet, are presented on Fig. 2. The data show that the bubaline milk has generally better health-related indicators than bovine. In the pre-experimental period the buffaloes had by 14 percent lower IA than the bovine cows, while the IT and the n6/n3 ratio are practically identical. Comparing the average values (for the three TD's) of the buffalo with the bovine cows

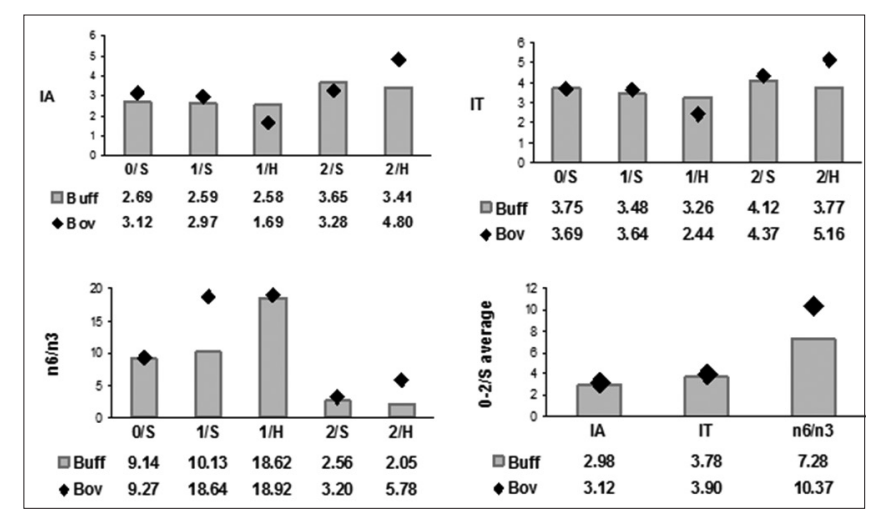

Fig 2. Index of atherogenicity (IA) and thrombogenicity (IT), and n6/n3 ratio in buffalo (Buff) and bovine (Bov) cows fed silage (/S) or hay $(/ \mathrm{H})$ at TD0 (0/), TD1 (1/), and TD2 (2/); and average values for silage groups

without an alteration of the diet (control groups on silage), IA and IT have close values, while the $\mathrm{n} 6 / \mathrm{n} 3$ ratio is by 30 percent more favourable in bubaline milk chiefly due to the difference at TD1. Noteworthy is the drastic improvement of the $n 6 / n 3$ ratio during the experiment in both species fed silage. No noticeable changes were found in the dynamics of IA and IT, with similarity between bubaline and bovine milk in this respect.

Considering the two health-related indices, some effect of the shift from silage to hay is seen in bovine cows only, with lower values at TD1 and higher at the end of the experiment, as compared to IA and IT from silage feeding. The ratio of essential FA (n6/n3) in the bovine cows after two-month hay feeding is also higher, while in the buffaloes the effect of hay on $\mathrm{n} 6 / \mathrm{n} 3$ can be considered positive, after being remarkably negative at TD1. Thus, in the experimental groups at the end of the period the differences in the three indicators are in favour of the buffalo milk.

\section{DISCUSSION}

The analyses carried out in the present study resulted in significant effects of the studied factors on most of the FA's after a two-month period, with RMSE values showing that the two sources of variance in the construction of the two-way ANOVA explain the variation of FA's contents to larger extent than that for TD1.

Although oxidation during hay production process is more detrimental to the favourable FA's than that during ensiling (Shingfield et al., 2005; Kalač and Samková, 2010), feeding hay results in improved PUFA in milk according to the results of Shingfield et al. (2005), Staszak (2007) and Bernardini et al. (2010). This appears to apply to the buffaloes in the present study with similarity in the effect of the shift in roughage source after one and two months, 
regardless of the differences in parity and lactation stage within the groups. In the same time, in the bovine cows the differences in the FA's between the diets are generally inconsistent as regarding the TD1 and TD2, which applies also to IA and IT. This might be due to the variation caused by parity and lactation stage.

Parity has been found to explain part of the variation in FA profile of milk in bovine and bubaline cows (Samková et al., 2012; Nogalski et al., 2012a; Qureshi et al., 2012). However, here the greater RSME values at TD1 suggest that this part is not big and the variation due to lactation stage is obviously more substantial at this phase of the experiment, while after one more month (TD2) it is diminished. This is on the background of the emphasized effect of the earlier months postpartum in lactating cattle (Stoop et al., 2009; Wang et al., 2013) and buffaloes (Sharma et al. 2000; Verdurico et al., 2012). Studies also demonstrate that for the significant individual variation in unsaturation of the milk fats also genetics plays a role, Kelsey et al. (2003) and Soyeurt et al. (2006) having even established that in cows the within-breed variation is greater than between breeds. Similarly, in national cattle Mihaylova (2007) has found greater variation among regions than among breeds, supported by Dimitrov (2007) for the Bulgarian Black and White breed. In the Bulgaian Murrah buffalo the author (Mihaylova, 2007) observed general uniformity among herds, with greater variability of 14- to 18-atom FA's (especially of the most highly presented palmitic acid) in our herd as compared to three other herds.

The effect of lactation stage on fatty acid composition of milk is mainly linked to body fat mobilization in early lactation (Nogalski et al., 2012b; Stoop et al., 2009). If we can rely on the three months of the present experiment and on the within-group differences among test days, the milk FA's from the bovine cows fed silage and hay show different patterns of alteration. As energetically poorer roughage, the shift to hay presumably appeared as a stress factor acting like negative energy balance, regardless of the lactation stage causing mobilization of long-chain FA's from body fat reserves. Bovine cows are more productive and have better expressed negative energy balance, as our practical observations show that Bulgarian Murrah buffaloes would the sooner compromise their milk production than change their lipid metabolism accordingly, and here they show a steady normal pattern of alteration of FA profile of milk, similar between the two groups, which explains their generally more consistent results mentioned above. In addition, as a species, the buffalo is also rather unpretentious to forage and such diet shift would not lead to some extreme misbalance. Only the buffaloes in our study show a tendency similar to the observed in the majority of research works in dairy cows proportional increase of short-chain and correspondingly decrease of long-chain FA's as lactation progresses (Samková et al., 2012). It partially applies to the Nili-Ravi breed (Qureshi et al., 2012) and the Mediterranean breed in Brazil (Verdurico et al., 2012), while in the Murrah breed in India the trend is opposite (Sharma et al., 2000).

The established herein lower contents of the medium-chain FA's lauric, myristic and palmitic in the buffalo and higher portion of the UFA fraction at TD0 and TD1, as compared to the cow milk, render its FA profile more favourable as they are associated with significant augmentation of plasma cholesterol level (Ulbricht and Southgate, 1991). Comparing it with bovine milk, some other studies have not found any practical differences in the FA profiles of bubaline milk from the Mediterranean breed (Ménard et al., 2010) and Nili-Ravi (Talpur, 2007). On the other hand, Kumar et al. (2013) found lower UFA and higher C14:0 and C16:0 in Murrah buffaloes than in cows, as similarly did Sharma et al. (2000). As was established herein, buffaloes produce milk with normally lower PUFA than cows (Talpur, 2007; Mihaiu et al., 2010). Taken for the bubaline milk alone, herein its atherogenic capacity over the experimental period is little greater than that in the latter studies and also than the majority of other works on variety of breeds worldwide (Bergamo et al., 2003; Chashnidel et al., 2007; Fernandes et al., 2007), and similar to few (Ménard et al., 2010; Talpur et al., 2007). In the buffaloes in our study it is worse in comparison to other herds of Bulgarian Murrah (Naydenova, 2005; Mihaylova, 2007), and little worse to similar as compared to previous states of the same herd (Mihaylova and Peeva, 2007; Tzankova and Dimov, 2003). The thrombogenic index is also higher as compared to Naydenova (2005) and similar to that of Talpur et al. (2007).

As for the content of linoleic and linolenic acid in milk, the research works have resulted in wide ranges in the buffalo (Mihaylova and Peeva, 2007; Ménard et al., 2010) and in dairy cattle (Mihaylova, 2007; Samková et al., 2012; Wang et al., 2013), as indicated by the variation between the test days and by the RMSE values in the present study, especially of C18:3. This suggests great individual differences in rumen environment mostly in the earlier months of lactation, as at TD2 the variability of C18:3 is considerably diminished. The dynamics of the linolenic acid is in disagreement with the discussed effect of lactation stage which might be due to augmented mobilization from body reserves, to enhanced mammary synthesis or to reduced biohydrogenation of this single FA. They also suggest different biohydrogenation from $\mathrm{C} 18: 2$, which is out of conformity with the similar pathway that these two PUFA's are known to follow (Chillard et al., 2000; Corl et al., 2001). 
If the degree of biohydrogenation can be judged by the level of stearic acid, as Nielsen et al. (2006) suggest, it is enhanced only in the bovine cows fed silage where to the decrease of linoleic acid corresponds an increase of C18:0. This does not meet the expectation for diminished biohydrogenation as a result of lower $\mathrm{pH}$ (Talpur, 2007) in response to silage feeding (Jalč et al., 2013), but in the buffaloes this is confirmed. In the present study the values of stearic acid in the buffalo milk are higher in comparison not only to the bovine milk but also to other results for the Bulgarian Murrah (Naydenova, 2005; Mihaylova and Peeva, 2007) and other breeds (Talpur et al., 2007; Varricchio et al., 2007). While in bovine milk worldwide the content of C18:0 varies in wide ranges (Samková et al., 2012; Beyero et al., 2015), on national scale the findings concerning mostly herds of Bulgarian Black and White cattle and other breeds are quite consistent (Mihaylova, 2007; Dimitrov, 2007), including our results. As we also found here, buffalo milk is considered to normally have lower levels of linoleic acid as compared to bovine milk elsewhere (Talpur, 2007; Ménard et al., 2010; Mihaiu et al., 2010), though for the Murrah breed Kumar and Kansal (2005) reported higher CLA levels. In association with it, the PUFA fraction is also lower in the buffalo milk, but it tends to improve when the roughage source of the diet is shifted from silage to hay (as it is with bovine milk as well). Moreover, as an n6 FA, C18:2 is in more favourable ratio with linolenic acid (n3) in the buffalo milk, especially obtained at TD2 - lower than the $\mathrm{n} 6 / \mathrm{n} 3$ ratio established by Tzankova and Dimov (2003) and comparable to that by Mihaylova (2007). Similar situation of lower C18:2 and higher C18:3 in buffalo milk, as compared to cow, is revealed also in the study of Mihaiu et al. (2010).

Our results about MUFA and oleic acid are not in agreement with the majority of studies (Talpur, 2007; Ménard et al., 2010; Kumar et al., 2013) reporting lower contents in buffalo milk. Earlier works (Ramamurthy and Narayanan, 1971; Bector and Narayanan, 1974) however found no such difference between the two milks.

\section{CONCLUSION}

There is similarity between the general FA profiles of bubaline and bovine milk with high presence of palmitic, oleic and also myristic acid. Still, there are some noticeable detailed differences, the buffaloes producing milk with lower total SFA, higher MUFA and n6/n3 ratio, but also with lower PUFA content and particularly linoleic acid. With regard to the effect of the shift in the roughage source on milk FA's, the buffaloes displayed more consistent results, all latter indicators (MUFA, PUFA, and n6/n3) tending to improve with the consumption of hay. The influence of the two-month hay feeding on the FA profile of the bovine milk is inconsistent and that on the three health-related indicators is the sooner adverse, the only similarity between the two species being the higher linoleic acid in the experimental groups.

\section{ACKNOWLEDGEMENTS}

The authors would like to acknowledge and thank Dr. Teodora Popova from the Institute of Animal Science - Kostinbrod for performing the fatty acid analyses.

\section{Authors' contributions}

P.P. carried out the statistical analyses, wrote the entire manuscript (in English), and prepared it for submission; together with R.K. conducted the experiment and the milk sample collection in the buffalo cows; together with Y.I. participated in the fatty acid analyses. Y.I. and T.I. conducted the experiment and the sample collection in the bovine cows. The design and the organization of the experiments were done mostly by R.K.

\section{REFERENCES}

Bauman, D. E., I. H. Mather, R. J. Wall and A. L. Lock. 2006. Major advances associated with the biosynthesis of milk. J. Dairy Sci. 89: 1235-1243.

Bector, B. S. and K. M. Narayanan. 1974. Effect of thermal oxidation on the fatty acid composition of ghee. J. Food Sci. Technol. 11: 224-226.

Bergamo, P., E. Fedele, L. lannibelli and G. Marzillo. 2003. Fat-soluble vitamin contents and fatty acid composition in organic and conventional Italian dairy products. Food Chem. 82: 625-631.

Bernardini, D., G. Gerardi, C. A. Elia, G. Marchesini, S. Tenti and S. Segato. 2010. Relationship between milk fatty acid composition and dietary roughage source in dairy cows. Vet. Res. Commun. 34: 135-138.

Beyero, N., V. Kapoor and B. S. Tewatia. 2015. Effect of different roughage: Concentrate ratio on milk yield and its fatty acid profile in dairy cows. J. Biol. Agric. Healthc. 5: 176-185.

Chashnidel, Y., H. Hafezian, B. Shohreh and K. Reza Yazdi. 2007. Seasonal variation in compositions and fatty acids profile (with emphasis on CLA) in Iranian buffalo's milk. Ital. J. Anim. Sci. 6 Suppl 2: 1053-1055.

Chillard, Y., A. Frelay, R. M. Mansbridge and M. Doreau. 2000. Ruminant milk fat plasticity: Nutritional control of saturated, polyunsaturated, trans and conjugated fatty acids. Ann. Zootech. 49: 181-205.

Corl, B. A., L. H. Baumgard, D. A. Dwyer, J. M. Griinari, B. S. Phillips and D. E. Bauman. 2001. The role of $\Delta 9$-desaturase in the production of cis-9, trans-11 CLA. J. Nutr. Biochem. 12: 622-630.

Dabadie, H., E. Peuchant, M. Bernard, P. LeRuyet and F. Mendy. 2005. Moderate intake of myristic acid in sn-2 position has beneficial lipidic effects and enhances DHA of cholesteryl esters in an interventional study. J. Nutr. Biochem. 16: 375-382.

Dhiman, T. R., G. R. Anand, L. D. Satter and M. W. Pariza. 1999. Conjugated linoleic acid content of milk from cows fed different 
diets. J. Dairy Sci. 82: 2146-2156.

Dimitrov, T. D. 2007. Scientific and applicable aspects in the production of quality bovine, ovine, and bubaline milk for the dairy industry. Dr. Agricultural Science Dissertation, Trakia University, Stara Zagora, p. 275. (In Bulgarian).

FAO/WHO (Food and Agriculture Organization/World Health Organization). 2003. Diet, nutrition and prevention of chronic diseases. WHO Technical Report Series \#916, Report of A Joint WHO/FAO Expert Conclusion, Geneva, p. 149.

Fernandes, S. A. A., W. R. S. Mattos, S. V. Matarazzo, H. Tonhati, M. A. S. Gama and D. P. D. Lanna. 2007. Total fatty acids in Murrah buffaloes milk on commercial farms in Brazil. Ital. J. Anim. Sci. 6 Suppl 2: 1063-1066.

Hara, A. and N. S. Radin. 1978. Lipid extraction of tissues with a lowtoxicity solvent. Anal. Biochem. 90: 420-426.

Jalč, D., Z. Váradyová, K. Mihaliková, V. Ledeckýand and S. Kišidayová. 2013. Enterococci inoculated silages: Effect on rumen fermentation and lipid metabolism in vitro. Afr. J. Microbiol. Res. 7: 4191-4199.

Kalač, P. and E. Samková. 2010. The effects of feeding various forages on fatty acid composition of bovine milk fat: A review. Czech J. Anim. Sci. 55: 521-537.

Kelsey, J. A., B. A. Corl, R. J. Collier and D. E. Bauman. 2003. The effect of breed, parity, and stage of lactation on conjugated linoleic acid (CLA) in milk fat from dairy cows. J. Dairy Sci. 86: 2588-2597.

Knopp, R. H. and B. M. Retzlaff. 2004. Saturated fat prevents coronary artery disease? An American paradox. Am. J. Clin. Nutr. 80: 1102-1103.

Kumar, A., D. Lal, A. Kumar, R. Seth and V. Sharma. 2013. Influence of seasonal variation on fatty acid composition and physico-chemical characteristics of milk fat. Indian J. Dairy Sci. 66: 502-506.

Kumar, J. S. and V. K. Kansal. 2005. Effects of breed and parity of animals, stage of lactation and processing of milk on the content of conjugated linoleic acid in dairy products. Milchwissenschaft. 60: $370-372$.

Ménard, O., S. Ahmad, F. Rousseau, V. Briard-Bion, F. Gaucheron and C. Lopez. 2010. Buffalo vs. Cow milk fat globules: Size distribution, zeta-potential, compositions in total fatty acids and in polar lipids from the milk fat globule membrane. Food Chem. 120: 544-551.

Mihaiu, R., M. Mihaiu, A. Pintea, C. Bele, A. Lapusan, S. D. Dan, C. Taulescu and A. Ciupa, 2010. Comparative study on the fat acids profile from buffalo milk as quality and traceability markers. Bull. UASVM Vet. Med. 67: 161-165.

Mihaylova, G. 2007. Fatty acid composition and functional properties of the lipids in milk and dairy products from different agroecosystems. Dr. Agricultural Science Dissertation, Trakia University, Stara Zagora, p. 306. (In Bulgarian).

Mihaylova, G. and T. Z. Peeva. 2007. Trans fatty acids and conjugated linoleic acid in the buffalo milk. Ital. J. Anim. Sci. 6 Suppl 2: 10561059.

Naydenova, N. 2005. Biological and technological properties of buffalo milk from the Bulgarian Murrah breed in dairy products manufacturing. PhD Thesis, Trakia University, Stara Zagora, p. 107. (In Bulgarian).

Newsholme, E. A., P. Calder and P. Yacoob. 1993. The regulatory, informational, and immunomodulatory roles of fat fuels. Am. J. Clin. Nutr. 57 Suppl: 738-751.

Nielsen, T., E. Straarup, M. Vestergaard and K. Sejrsen. 2006. Effect of silage type and concentrate level on conjugated linoleic acids, trans-C18:1 isomers and fat content in milk from dairy cows.
Reprod. Nutr. Dev. 46: 699-712.

Nogalski, Z., B. Jaglowska, S. Wielgosz-Groth, P. PogorzelskaPrzybyliek, M. Sobczuk-Szul and M. Mochol. 2012a. The effect of parity on the fatty acid profile of milk from high-yielding cows. Acta Sci. Pol., Zootech. 11: 49-56.

Nogalski, Z., M. Wronski, M. Sobczuk-Szul, M. Mochol and P. Pogorzelska. 2012b. The effect of body energy reserve mobilization on the fatty acid profile of milk in high-yielding cows. Asian Aust. J. Anim. Sci. 25: 1712-1720.

Parodi, P. W. 2004. Milk fat in human nutrition. Aust. J. Dairy Technol. 59: 3-59.

Qureshi, M. S., S. Jan, A. Mushtaq, I. U. Rahman, M. Jan and Ikramullah. 2012. Effect of age on milk fatty acids in dairy buffaloes. J. Anim. Plant Sci. 22 Suppl 2: 108-12.

Ramamurthy, M. K. and K. M. Narayanan. 1971. Fatty Acid compositions of buffalo and cow milk fats by gas liquid chromatography (GLC). Milchwissenschaft. 26: 693-696.

Samková, E., J. Špička, M. Pešek, T. Pelikánová and O. Hanuš. 2012. Animal factors affecting fatty acid composition of cow milk fat: A review. S. Afr. J. Anim. Sci. 42: 83-100.

Sharma, K. C., V. K. Sachdeva and S. Singh. 2000. A comparative gross and lipid composition of Murrah breed of buffalo and cross-bred cow's milk during different lactation stages. Arch. Tierz. Dummerstorf. 43: 123-130.

Shingfield, K. J., P. Salo-Väänänen, E. Pahkala, V. Toivonen, S. Jaakkola, V. Piironen and P. Huhtanen. 2005. Effect of forage conservation method, concentrate level and propylene glycol on the fatty acid composition and vitamin content of cows'mik. J. Dairy Res. 72: 349-361.

Soyeurt, H., P. Dardenne, A. Gillon, C. Croquet, S. Vanderick, P. Mayeres, C. Bertozzi and N. Gengler. 2006. Variation in fatty acid contents of milk and milk fat within and across breeds. J. Dairy Sci. 89: 4858-4865.

Staszak, E. 2007. Fatty acid content of milk from cows fed different diets. Ann. Anim. Sci. 7: 123-130.

Stoop, W. M., H. Bovenhuis, J. M. L. Heck and J. A. M. Van Arendonk. 2009. Effect of lactation stage and energy status on milk fat composition of Holstein-Friesian cows. J. Dairy Sci. 92: 1469-1478.

Talpur, F. N. 2007. Fatty Acid Composition of Ruminant Milk, Meat and Dairy Products of Livestock in Sindh, Pakistan. Ph.D. Thesis, Univ Sindh, Jamshoro, Pakistan, p. 194.

Talpur, F. N., N. N. Memon and M. I. Bhanger. 2007. Comparison of fatty acid and cholesterol content of Pakistani water buffalo breeds. Pak. J. Anal. Environ. Chem. 8: 15-20.

Tzankova, M. and K. Dimov. 2003. Fatty acid composition of milk from Bulgarian Murrah buffalo cows. Bulg. J. Agric. Sci. 9: 397-400.

Ulbricht, T. L. V. and D. A. T. Southgate. 1991. Coronary heart disease: Seven dietary factors. Lancet. 338: 985-992.

Varricchio, M. L., A. Di Francia, F. Masucci, R. Romano and V. Proto. 2007. Fatty acid composition of Mediterranean buffalo milk fat Ital. J. Anim. Sci. 6 Suppl 1: 509-511.

Verdurico, L. C, J. R. Gandra, J. E. de Freitas Jr., R. V. Barletta, B. C. Venturelli, R. D. Mingoti, T. H. A. Vendramini and F. P. Rennó. 2012. Evaluation of the milk fatty acid profile from Mediterranean buffalo cows in the first eight weeks of lactation. J. Buffalo Sci. 1: $177-182$.

Wang, T., J. J. Oh, J. N. Lim, J. E. Hong, J. H. Kim, J. H. Kim, H. S. Kang, Y. J. Choi and H. G. Lee. 2013. Effects of lactation stage and individual performance on milk cis- 9 , trans-11 conjugated linoleic acids content in dairy cows. Asian-Aust. J. Anim. Sci. 26: 189-194. 